\title{
Evaluation in a Shrimp Aquaculture System Using Mangroves, Oysters, and Seaweed as Biofilters Based on the Concentrations of Nutrients and Chlorophyll $a$
}

\author{
Toru SHIMODA ${ }^{1,3 *}$, Emma SURYATI ${ }^{2}$ and Taufic AHMAD ${ }^{2}$ \\ ${ }^{1}$ Fisheries Division, Japan International Research Center for Agricultural Sciences (JIRCAS) \\ (Tsukuba, Ibaraki 305-8686, Japan) \\ ${ }^{2}$ Research Institute for Coastal Fisheries, Indonesia \\ (Jl. Makmur Dg. Sitakka No. 129, Maros, South Sulawesi 90512, Indonesia)
}

\begin{abstract}
Water from shrimp aquaculture ponds was circulated through a mangrove woodlot, oyster beds, and seaweed ponds in biofilter experiments designed to reduce environmental loads. Though the nutrient concentrations in the shrimp culture ponds were lower than those in the other ponds in many cases, the Chl. $a$ concentration increased explosively in shrimp ponds and exceeded $160 \mu \mathrm{g} / \mathrm{L}$. These results suggested that nutrients were used for the growth of phytoplankton. The Chl. $a$ concentration was very low in the oyster pond, and it was suggested that oyster feed actively on phytoplankton. Ammonia was always lower in the seaweed ponds than in the oyster ponds, which suggested that seaweed took up ammonia. From the nitrogen budget, $27 \%$ of nitrogen in supplied feed was incorporated into shrimp, $32 \%$ was flowed to mangrove, oyster and seaweed ponds and removed with these biofilters, and $9 \%$ was added in the aquaculture system as dissolved inorganic and particulate nitrogen. Therefore, this aquaculture system using mangroves, oyster and seaweed as biofilters was thought to be effective to reduce the environmental load.
\end{abstract}

Discipline: Aquaculture

Additional key words: budget, environment, nitrogen, phosphorus, phytoplankton

\section{Introduction}

In Southeast Asian countries, including Indonesia, shrimp aquaculture has been performed actively to acquire foreign currency. The coastal area, which includes mangrove forests, has been destroyed to develop aquaculture ponds ${ }^{2}$. Moreover, effluent, which contains a large quantity of nutrients as a result of feed and fertilizer, has been discharged from aquaculture ponds, resulting in environmental deterioration in the coastal waters. In intensive marine shrimp culture, only $24 \%$ of the nitrogen and $13 \%$ of the phosphorus of the feed input was incorporated into the shrimp harvested, while the remainder was retained in the ponds and ultimately exported to the surrounding water ${ }^{1}$. The nutrient levels during harvest were exceeding or near the limitations recommended by the U.S. Environment Protection Agency ${ }^{3}$. On the other hand, tidal mangrove estuaries impacted on shrimp pond effluent, have some capacity to process intermittent inputs of pond-derived nutrients ${ }^{5,14}$. Silvofisheries, or aquasilviculture, in which low-density cultures are integrated with mangroves, have been reviewed by Primavera ${ }^{6}$, but the use of mangroves to process effluent from shrimp aquaculture sources is still not generally practiced $^{9}$. In this research, water from shrimp ponds was circulated through a mangrove woodlot, oyster beds, and seaweed ponds in biofilter experiments designed to reduce environmental loads. The effectiveness of this aquaculture system was examined based on the concen-

This paper is a report of the results of collaborative research based on a Memorandum of Understanding between the Agency for Agricultural Research and the Ministry of Agriculture of the Republic of Indonesia and the Japan International Research Center for Agricultural Sciences (JIRCAS).

Present address:

${ }^{3}$ Ishigaki Tropical Station, Seikai National Fisheries Research Institute (Ishigaki, Okinawa 907-0451, Japan)

*Corresponding author: fax +81-980-88-2573; e-mail ts77@fra.affrc.go.jp

Received 25 March 2005; accepted 31 August 2005. 
trations of nutrients and Chl. $a$.

\section{Materials and methods}

This experiment was conducted at the Maranak experiment station, Research Institute for Coastal Fisheries, South Sulawesi, Indonesia. The investigation site is shown in Fig. 1. Water from 7 shrimp aquaculture ponds was introduced into a mangrove (Rhizophora sp.) woodlot through canal 1. The mangrove stands consisted of saplings aged 0 to 2 years planted in ponds at intervals of $40 \mathrm{~cm}$. Although the mangrove woodlot was divided into

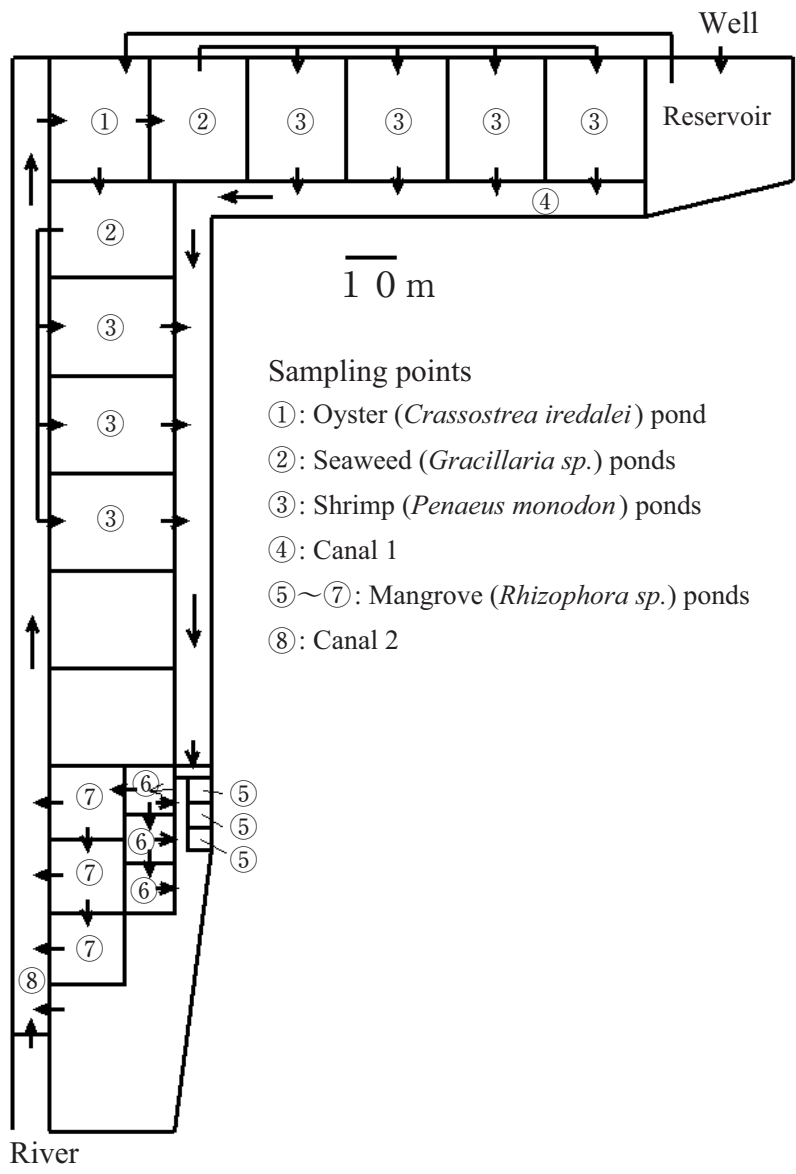

Fig. 1. Schematic outline of shrimp aquaculture, mangrove, oyster, and seaweed ponds used in the experiments and sampling points
9 parts consisting of 3 divisions each of $5 \times 5 \mathrm{~m}, 10 \times 10$ $\mathrm{m}$, and $15 \times 15 \mathrm{~m}$, there were no differences in nutrients or Chl. $a$ concentrations among the mangrove ponds. Therefore they were treated collectively. Water that had passed through the mangrove woodlot was returned to the shrimp aquaculture ponds via oyster (Crassostrea iredalei) and seaweed (Gracillaria sp.) ponds. Thirty percent of the water in the shrimp ponds was exchanged every 3 days. Water evaporation and seepage into the soil were compensated for by supplying river or well water depending on the salinity in the aquaculture ponds. Shrimp aquaculture was intensively ${ }^{4}$ carried out for about 3 months from August to November, 1999, at a density of 20 individuals $/ \mathrm{m}^{2}$ (Table 1).

Every 15 days, the water quality was investigated at each site in the early morning before circulation. The water temperature, salinity, and dissolved oxygen (DO) were monitored with a TOA model WQC-20A water quality checker. Water samples were collected using plastic bottles installed at the edge of a stick. They were immediately filtered through Whatman GF/F filters for Chl. $a$ and nutrients analyses. For Chl. $a$ analysis, the filters were soaked in $N, N$-dimethylformamide ${ }^{12}$, and then Chl. $a$ was extracted in solvent and analyzed with a fluorometer (Shimadzu RF-5300). The ammonia concentration in filtrate was measured immediately after filtration using the Sasaki and Sawada's method ${ }^{10}$. Nitrate, nitrite, phosphate, and silicate concentrations were measured by the standard $\operatorname{method}^{7}$ using a spectrophotometer (Shimadzu UV-2400).

The experiment site was divided into 5 divisions: shrimp aquaculture ponds, canal 1 from shrimp ponds to mangrove ponds, mangrove ponds, canal 2 from mangrove ponds to an oyster pond, and oyster + seaweed ponds. Oyster and seaweed ponds were treated in a lump because there was no partition board between both ponds and water was able to move between both ponds at any time. The amount of variation in nutrients and Chl. $a$ in each division was calculated every 3 days, as water was circulated every 3 days, and the budget in each division was estimated as follows:

Table 1. Outline of the shrimp culture indicated by the stocked larvae, days of culture, shrimp total weight, number of individuals at harvest, amount of feed, and feed conversion ratio (FCR)

\begin{tabular}{|c|c|c|c|c|c|c|c|}
\hline \multicolumn{2}{|c|}{ Stocked larvae } & \multirow{2}{*}{$\begin{array}{c}\text { Cultured days } \\
\text { (day) }\end{array}$} & \multicolumn{2}{|c|}{ Harvest } & \multirow{2}{*}{$\begin{array}{c}\text { Survival rate } \\
(\%)\end{array}$} & \multirow{2}{*}{$\begin{array}{l}\text { Feed } \\
(\mathrm{kg})\end{array}$} & \multirow[t]{2}{*}{ FCR } \\
\hline Individuals & $(\mathrm{kg})$ & & Individuals & $(\mathrm{kg})$ & & & \\
\hline 70,000 & 15.05 & 92 & 36,754 & 622.6 & 52.51 & 950 & 1.56 \\
\hline
\end{tabular}


$\mathrm{Cd}, \mathrm{n}^{*}=(\mathrm{Cd}, \mathrm{n}-1 \times \mathrm{Vtd}, \mathrm{n}-1+\mathrm{Cd}, \mathrm{n} \times \mathrm{Vd}, \mathrm{n}) /(\mathrm{Vtd}, \mathrm{n}-1+\mathrm{Vd}, \mathrm{n})$ $\mathrm{B}=\Sigma\left(\mathrm{Cd}+3, \mathrm{n}-\mathrm{Cd}, \mathrm{n}^{*}\right) \times \mathrm{Vd}, \mathrm{n}$

$\mathrm{Cd}, \mathrm{n}^{*}$ : concentration in division $\mathrm{n}$ after water exchange at d day

$\mathrm{Cd}, \mathrm{n}$ : concentration in division $\mathrm{n}$ before water exchange at $\mathrm{d}$ day

Vtd,n-1: volume of water transportation from division $\mathrm{n}-1$ to $\mathrm{n}$ at $\mathrm{d}$ day

$\mathrm{Vd}, \mathrm{n}$ : volume of division $\mathrm{n}$ at $\mathrm{d}$ day

B: budget in each division

When the budget B is plus, the division is a source of material, and, when the budget is minus, it is a sink.

To acquire the nitrogen and phosphorus budget in this aquaculture system, the nitrogen content in shrimp and feed was analyzed with an elemental analyzer (FISONS EA-1108), and the phosphorus content was analyzed by the modified method of Solórzano and Sharp ${ }^{11}$. Assuming that the Carbon:Chl. a ratio was 50 and that the C:N:P ratio was $106: 16: 1$ in phytoplankton ${ }^{8}$, the particulate nitrogen and phosphorus concentrations in water were estimated from the Chl. $a$ concentration.

\section{Results and discussion}

The water temperature ranged from 24.8 to $30.1^{\circ} \mathrm{C}$. Salinity fluctuated largely from 27.5 to 44.5 (psu). It was high at the beginning of the experiment because of the dry season, and well water was supplied to the oyster pond. Dissolved oxygen ranged from 1.70 to $8.36 \mathrm{mg} / \mathrm{L}$, and it was always low at canal 1 and in the mangrove ponds. It was assumed that oxygen was consumed, since organic matter was decomposed there.

The ammonia concentration increased gradually in the oyster pond and exceeded $100 \mu \mathrm{M}$ once, and the silicate concentration progressively increased as well (Fig. 2). Though well water was supplied to the oyster pond, the ammonia and silicate concentrations in well water were very high, about $200 \mu \mathrm{M}$ and $130 \mu \mathrm{M}$, respectively. Moreover, the Chl. $a$ concentration was very low (Fig. 3), which suggests that oysters feed actively on phytoplankton. Therefore, the increase in ammonia and silicate concentrations in the oyster pond was attributed to the supply from the well and/or excrement from the oysters. Though the ammonia concentration in the oyster pond and seaweed ponds was synchronized, it was always low in the seaweed ponds, which suggests that


Fig. 2. Concentrations of ammonia, nitrate, nitrite, phosphate, and silicate during the experimental period 


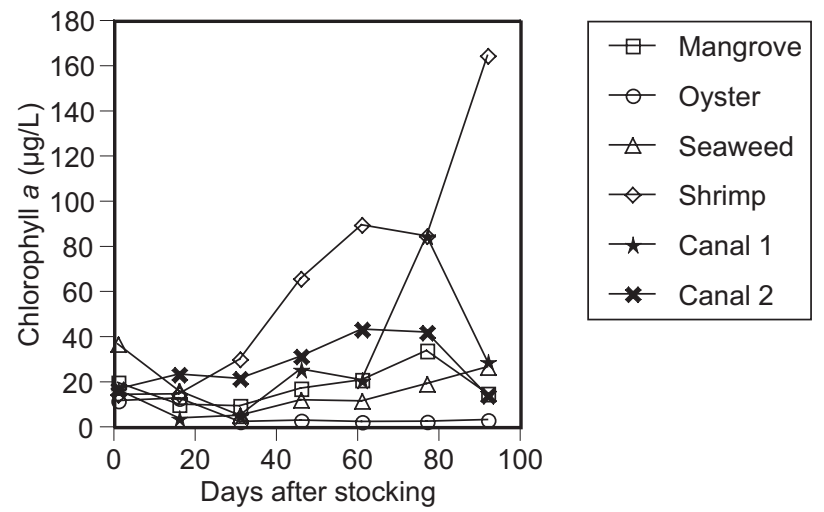

Fig. 3. Chlorophyll $a$ concentration during the experiment period

seaweed took up ammonia. Since little amounts of nitrate and nitrite were observed in the well water, they might have been generated by nitrifying bacteria. The phosphate concentration was about $0.7-0.8 \mu \mathrm{M}$ in river water, and it was assumed that the high initial concentration of phosphate was influenced by river water. Though the nutrient concentrations in shrimp culture ponds were lower than those in oyster and seaweed ponds in many cases, the Chl. $a$ concentration increased explosively in shrimp ponds and exceeded $160 \mu \mathrm{g} / \mathrm{L}$. The results, therefore, suggested that nutrients were used for the growth of phytoplankton. A high Chl. a concentration was observed in shrimp aquaculture ponds in Thailand and Malaysia $^{1,3}$, which suggested that nitrogen and phosphorus were discharged into the environment in the form of particulate organic matter rather than in the form of nutrients. In mangrove ponds, water with low nutrients concentrations was supplied because nutrients were taken up by phytoplankton in aquaculture ponds. Phytoplankton sank in mangrove ponds because there was no water circulation created by a paddlewheel, different from the case in the aquaculture ponds. Therefore, Chl. $a$ concentration was comparatively low in mangrove ponds. Ammonia

Table 2. Nutrients and Chl. $a$ budgets in each division

\begin{tabular}{lcccccc}
\hline \hline & $\begin{array}{c}\mathrm{NH} 4 \\
(\mathrm{kgN})\end{array}$ & $\begin{array}{c}\mathrm{NO} 3 \\
(\mathrm{kgN})\end{array}$ & $\begin{array}{c}\mathrm{NO} 2 \\
(\mathrm{kgN})\end{array}$ & $\begin{array}{c}\mathrm{DIN} \\
(\mathrm{kgN})\end{array}$ & $\begin{array}{c}\text { PO4 } \\
(\mathrm{kgP})\end{array}$ & $\begin{array}{c}\text { Chl. } a \\
(\mathrm{kgChl} . a)\end{array}$ \\
\hline Canal 1 & 4.45 & 0.53 & 0.10 & 5.09 & -0.03 & -0.31 \\
Mangrove & 0.09 & -0.31 & -0.03 & -0.25 & -0.01 & -0.23 \\
Canal 2 & -0.46 & 0.01 & -0.01 & -0.46 & 0.05 & -0.17 \\
Oyster + Seaweed & 5.52 & 1.97 & 0.36 & 7.85 & -0.04 & -0.33 \\
Shrimp & -8.90 & -1.93 & -0.43 & -11.27 & 0.00 & 1.56 \\
\hline
\end{tabular}

If the value is a plus, it indicates that the division is a source.

If the value is a minus, it indicates that the division is a sink.

Table 3. Parameters and results of nitrogen budget in this experiment

\begin{tabular}{lc}
\hline \hline Supplied feed (Wet weight) & $950.0 \mathrm{~kg}$ \\
Dry/wet weight ratio in feed & $94.6 \%$ \\
Nitrogen/dry weight ratio in feed & $7.3 \%$ \\
Harvest (Wet weight) & $622.6 \mathrm{~kg}$ \\
Dry/wet weight ratio in prawn at the harvest & $27.1 \%$ \\
Nitrogen/dry weight ratio in shrimp at harvest & $10.8 \%$ \\
Initial weight of total shrimp & $15.1 \mathrm{~kg}$ \\
Dry/wet weight ratio in shrimp at the start & $22.6 \%$ \\
Nitrogen/dry weight ratio in shrimp at the start & $9.8 \%$ \\
Sediment amount/feed ratio (modified Briggs \& Funge-Smith $\left.{ }^{1}\right)$ & $32.0 \%$ \\
Increase in dissolved inorganic and particulate matter & $5.6 \mathrm{~kg}$ \\
& \\
Remainder & $21.0 \mathrm{~kg}$ \\
Area (Mangrove + Oyster + Seaweed ponds) & \\
Days & $2,550 \mathrm{~m}$ \\
Removal rate & $92 \mathrm{day}$ \\
\hline
\end{tabular}


and nitrate decreased in canal 2 compared with canal 1 and mangroves might remove nutrients or nutrients might be taken up by phytoplankton since Chl. $a$ concentration was high in canal 2.

From the budgets of nutrients and Chl. $a$ in each division (Table 2), dissolved inorganic nitrogen increased in the canal 1 and oyster + seaweed ponds, while it decreased in the shrimp ponds. Canal 1 was suggested as the place where organic material was decomposed and generation of nutrients were regenerated. As decomposition might be nearly in balance with the uptake by the mangroves, there was little increase and decrease in the mangrove ponds. Then the nutrients were taken up by the phytoplankton in the shrimp culture ponds. The nitrogen supply from the well water was larger in the oyster + seaweed ponds. Phytoplankton proliferated in aquaculture ponds and decreased in all the other ponds. Therefore phytoplankton played an important role of nutrients cycle in this aquaculture system. Though there was no clear tendency in the phosphate, it was known that phosphorus was desorbed from the sediment in the culture pond $^{1}$, and the amount of desorption in culture ponds might be balanced with the uptake by the phytoplankton.

Ten thousand post larvae (PL-45) were stocked in each shrimp pond, $950 \mathrm{~kg}$ of pelleted feed was supplied to culture ponds, and $622.6 \mathrm{~kg}$ of shrimp was harvested (Table 1). The feed conversion ratio (FCR) is usually measured as the total feed input $(\mathrm{kg}) /$ total shrimp weight gain $(\mathrm{kg})$ and global average shrimp feed conversion ratio was $2.0^{13}$. FCR in this study was 1.56 and not wrong.

From the budget (Table 3), 27\% of nitrogen in supplied feed $(65.2 \mathrm{kgN})$ was incorporated into shrimp and $9 \%(5.6 \mathrm{kgN})$ was added with aquaculture system as dissolved inorganic and particulate nitrogen. With the assumption that the sedimentary amount of feed was $32 \% 1,32 \%$ was flowed to mangrove, oyster and seaweed ponds and $21 \mathrm{kgN}\left(89.5 \mathrm{mgN} / \mathrm{m}^{2} /\right.$ day $)$ was removed by biofilter (Table 3). Our results would be underestimated because the ammonia supply from the well was not considered. Riviera-Monroy ${ }^{9}$ indicated that the treatment capacity in riverine forest mangroves was $113-122 \mathrm{mgN} /$ $\mathrm{m}^{2} /$ day, and the results obtained in this study were comparable with theirs. Phosphorus increased by the effect of desorption. However, phosphate concentration decreased from the initial concentration. Therefore, this aquaculture system was probably effective in reducing the environmental load.

\section{References}

1. Briggs, M. R. P. \& Funge-Smith, S. J. (1994) A nutrient budget of some intensive marine shrimp ponds in Thailand. Aquaculture and Fish. Manage., 25, 789-811.

2. Clough, B. F. (1993) Status and value of mangrove forests. In The economic and environmental values of mangrove forests and their present state of conservation in the South-East Asia/Pacific region, Mangrove ecosystems technical reports vol. 1, ISME/ITTO/JIAM Project PD71/ 89 Rev.1 (F), ISME, Okinawa, Japan, 1-10.

3. Choo, P. -S. \& Tanaka, K. (2000) Nutrient levels in ponds during the grow-out and harvest phase of Penaeus monodon under semi-intensive culture. JIRCAS J., 8, 13-20.

4. Motoh, H. (1992) Black tiger. In Aquaculture in southeast Asia, ed. Yoshida, Y., Kouseisha Kouseikaku, Tokyo, 35-48 [In Japanese].

5. McKinnon, A. D. et al. (2002) Water column production and nutrient characteristics in mangrove creeks receiving shrimp farm effluent. Aquaculture Res., 33, 55-73.

6. Primavera, J. H. (2000) Integrated mangrove-aquaculture systems in Asia. In Integrated coastal zone management, autumn ed., 121-130. Available online at http:// www.iucn.org/themes/ceesp/Publications/SL/Aquaculture-JPrimavera.pdf (Verified 4 Jan. 2006).

7. Parsons, T. R., Maita, Y. \& Lalli, C. M. (1984) A manual of chemical and biological methods for seawater analysis. Pergamon Press, Oxford, pp.173.

8. Redfield, A. C. (1934) On the proportions of organic derivations in sea water and their relation to the composition of plankton. In James Johnston memorial volume, Liverpool University Press, Liverpool, 176-192.

9. Riviera-Monroy, V. H. et al. (1999) The potential use of mangrove forests as nitrogen sinks of shrimp aquaculture pond effluents: The role of denitrification. J. World Aquaculture Soc., 30(1), 12-25.

10. Sasaki, K. \& Sawada, Y. (1980) Determination of ammonia in estuary. Bull. Jpn. Soc. Sci. Fish., 46(3), 319-321.

11. Solórzano, L. \& Sharp, J. H. (1980) Determination of total dissolved phosphorus and particulate phosphorus in natural waters. Limnol. Oceanogr., 25, 754-758.

12. Suzuki, R. \& Ishimaru, T. (1990) An improved method for the determination of phytoplankton chlorophyll using $N, N$-dimethylformamide. J. Oceanogr. Soc. Jpn., 46, 190-194.

13. Tacon, A. G. J. (2002) Thematic review of feeds and feed management practices in shrimp aquaculture. Report prepared under the World Bank, NACA, WWF and FAO consortium program on shrimp farming and the environment, published by the consortium, pp.69. Available online at http://www.enaca.org/modules/mydownloads/ singlefile.php?cid\&lid=154 (Verified 4 Jan. 2006).

14. Trott, L. A. \& Alongi, D. M. (2000) The impact of shrimp pond effluent on water quality and phytoplankton biomass in a tropical mangrove estuary. Mar. Pollut. Bull., 40(11), 947-951. 